\title{
The Status of Women in American Higher Education
}

\author{
Carol Frances
}

Claremont Graduate University, USA

Copyright $\bigcirc 2018$ by authors, all rights reserved. Authors agree that this article remains permanently open access under the terms of the Creative Commons Attribution License 4.0 International License

\begin{abstract}
This is a comprehensive overview of the status of women using charts to document trends. The charts are divided into two parts. Part 1 charts in the demographic domain show the spectacular success of women beginning to outnumber men as early as 1980 in the college-going rate, college enrollments, and earned degrees. By 2010 women even earned more doctorate degrees than men. More women than men are employed in higher education in every position, including administration. Part 2 charts show a dismaying lack of continuing success of women in the economic domain of higher education. The number of bachelor degrees earned by women has fallen off from earlier peaks in all the STEM fields. Degrees earned by women continue to be predominantly in the lower paying social science fields. Women professors are paid less than men and the salary gap continues to grow. After huge gains in the number of professional degrees earned by women, the trends have plateaued in recent years. Finally, the number of women college presidents and the number of women serving on governing boards has hit low ceilings. The paper concludes with a search for explanations of these trends and recommendations for aggressive action to restore progress toward equality and equity for women in American higher education.
\end{abstract}

Keywords Higher Education, Gender Equality, Gender Equity, Salary Gap, STEM

\section{Introduction}

While serving as Chief Economist of the American Council on Education forty years ago in the late 1970s, I worked with Frank Mensel, the Governmental Relations Officer of the College and University Personnel Association (CUPA) to launch a pioneering study of women and minorities in higher education administration. The study was funded by the Ford Foundation and benefitted from access to richly detailed data from the CUPA annual surveys. On the basis of careful analysis of the CUPA data we found lower participation and lower salaries for the women and minorities than for their men counterparts.

We invited comment on the findings and accumulated possible explanations, other than discrimination, suggested by critics of the study to account for the disparities. For instance, it was argued that women and minorities were probably employed in their positions for shorter periods of time than men and therefore had lower salaries.

We then conducted a second study three years later, also funded by the Ford Foundation, to update the earlier study and to test the possible explanations, other than discrimination, for the disparities we had found. [1] In the case of the length of employment in their positions, for instance, we found that the longer the women and minorities had been employed in their jobs, the greater was the gap in their salary below the salary of men in comparable jobs.

In the following decades other studies were conducted of the status of women serving in particular roles within American higher education. An especially outstanding study was done in the late 1990s at MIT by the six faculties within the Department of Science. Interviews uncovered the fact that while younger women faculty felt more or less adequately supported, the more senior women felt increasingly marginalized. [2, 3]

This current study attempts to be added to this field of study in two ways, first by attempting to be more comprehensive than previous studies by examining the status of women across a broad spectrum of situations--as students, as the earners of degrees, as faculty and administrators, and as college and university presidents and members of governing boards.

Second, this study attempts to add to the field by showing historical trends over thirty to forty years thereby generating perspectives which could be used by others, including especially sociologists and anthropologists, to help explain the trends and sharpen recommendations for achieving equality and equity for women in American higher education.

The historical trends can best be documented and displayed using charts. Based on analysis of the trend data, 
the charts are divided into two categories.

Part 1 charts document the phenomenal success of women in increasing participation in American higher education over recent decades. Enrollment of women students in American colleges and universities has soared. Many more women are earning bachelor's, master's, and even doctorate degrees More women are becoming faculty at all ranks, including assistant, associate, and full professor. More women are employed on college campuses in both professional and non-professional jobs. More women are employed in administrative and managerial positions.

Part 2 charts document the utterly dismaying lack of success of women in making significant progress toward equality in the economic domain of American higher education. The gap between the salaries of women and men professors has not narrowed-it has widened. Men dominate the higher paying physical sciences, while women dominate the lower paying social sciences, now as they have over the last forty years. A much higher percentage of men faculty than women faculty are full professor who earn the highest salaries. Women do less than men of the research in higher education, which is the higher paying faculty activity.

The number of women serving on college and university boards of trustees increased markedly from about 20 percent in the 1970s to about 30-35 percent the 1990s. There has been barely any further increase over the most recent 20 years, effectively hitting a low ceiling.

The sources of data for the charts are the U.S. Department of Education, National Center for Education Statistics [4]; the National Science Foundation, National Center for Science and Engineering Statistics [5]; and education associations, including the American Council on Education and the Association of Governing Boards of Universities and Colleges.

Next is speculation about what might be factors driving success in the demographic domain on the one hand, and driving the lack of success in the economic domain on the other hand. The report concludes with ideas primarily in the political domain about how women might accelerate progress toward greater equality and equity in American higher education.

\section{The Great Success of Women in the Demographic Domain}

\subsection{Trends in Overall College-Going Rates}

The first indication of the growing success of women in American higher education is the increasing college-going rate of 18-24 year-old women. In the early 1970s the college-going rate of the men of 32 percent, was half again as high as the 21 percent of the women. By the late 1980s and early 1990s, the college-going rate of women had equaled the rate for men. Currently, the college-going rate of the women exceeds that of men by 5 to 6 percentage points, with about 43 percent for women and about 38 percent for men.

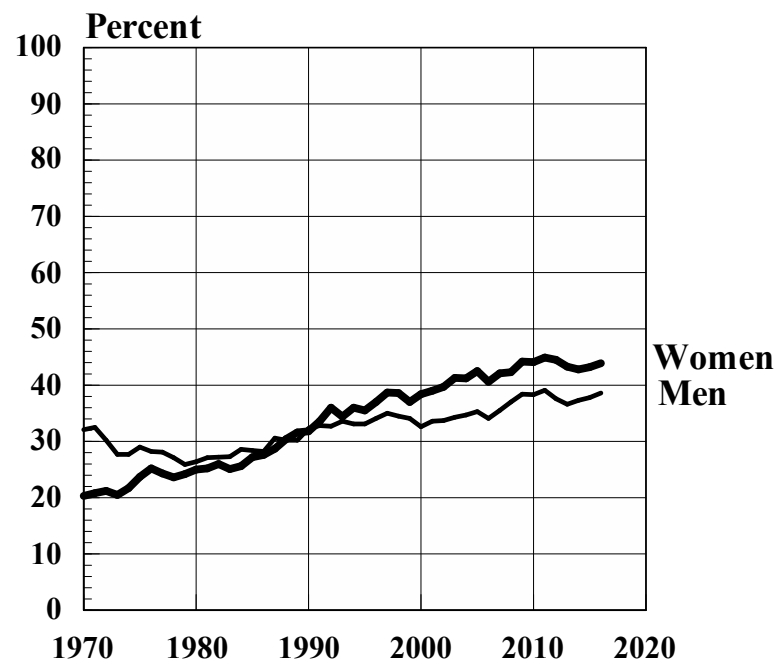

Source: U.S. Department of Education, National Center for Education Statistics, Digest of Education Statistics: 2017, Table 302.60.

Chart 1. Trends in the College-Going Rate of 18-To-24 Year-Olds, 1970-2016, By Gender

\subsection{Trends in College-Going Rates of High School Completers}

For a somewhat more comprehensive view of the comparative participation of women and men in higher education we should look at the trends in the college-going rates of girls and boys who complete high school and who then enroll in college. In 2016 there were just over 3.1 million high school completers in the United States. Of these, slightly more than half, 1.6 million, were girls compared with 1.5 million who were boys.

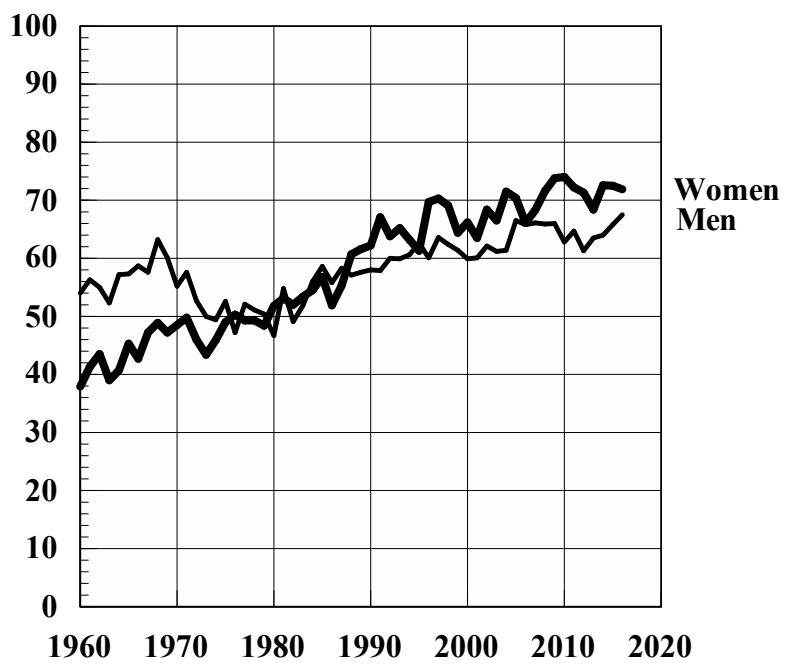

Source: U.S. Department of Education, National Center for Education Statistics, Digest of Education Statistics: 2017, Table 302.10.

Chart 2. Trends in College-Going Rates of High School Completers, 1960-2016, By Gender 
As shown on Chart 2, up until about 1970 a much higher percentage of boys than girls completing high school went on to enroll in college that same year. In the 1980s the girls who were high school completers caught up with the boys in the rate of enrollment in college.

Then beginning in the 1990s, the girls completing high school enrolled in college have higher rates than boys. By 2016 the college-enrollment of girls who had completed high school was 71.9 percent slightly higher than the 67.5 percent for boys.

\subsection{Trends in College Enrollment by Gender}

The United States is witnessing a spectacular increase in the number of women enrolled in American colleges and universities since the 1940s. Women began to exceed the number of men enrolled in college in 1980 and the gap has widened ever since. In 2016 college enrollment totaled just over 20 million, with the number of women of 11.3 million, exceeding the number of men of 8.9 million by 2.4 million.

Disaggregating the data by enrollment status we find that women exceeded men in full-time enrollment by 1990 , an in part-time enrollment a decade earlier, in 1980.

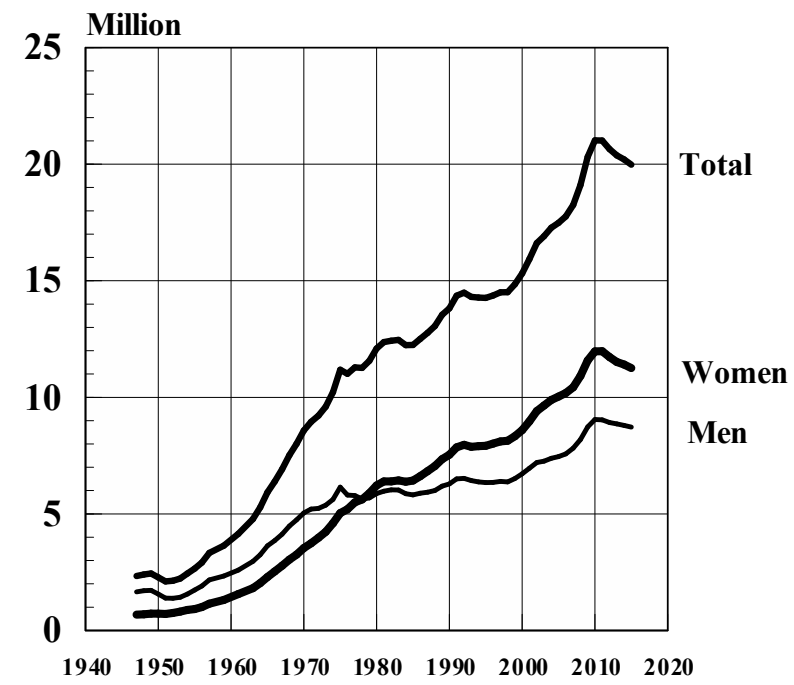

Source: U.S. Department of Education, National Center for Education Statistics, Digest of Education Statistics: 2017, Table 302.10.

Chart 3. Trends in Enrollment in American Colleges and Universities, 1947-2015, By Gender

\subsection{Percentage of Undergraduates and Graduates Who Are Women}

More than half of undergraduate students were women by 1980 and more than half of graduate (postbacalaureate) students were women by 1990. Since about 2000 the percentage of women by enrollment level has stayed about the same, hovering close to 56 percent of undergraduate students and slightly higher at close to 58 percent of graduate students.

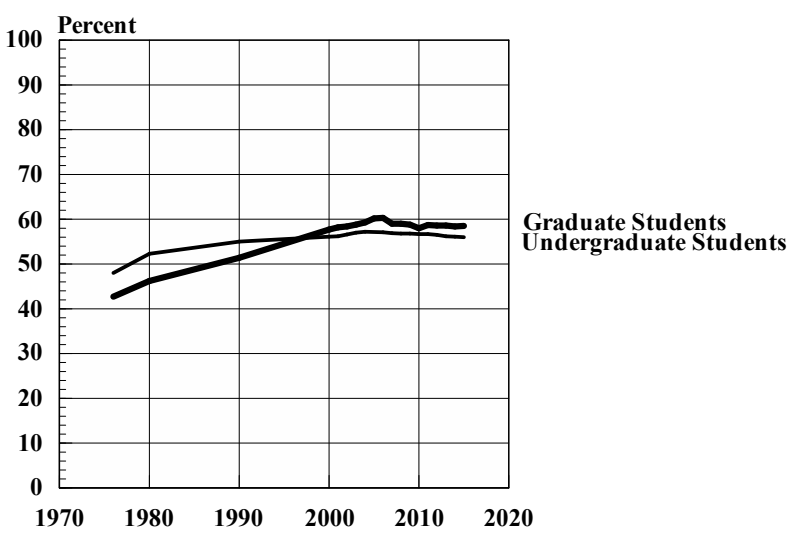

Source: U.S. Department of Education, National Center for Education Statistics, Digest of Education Statistics: 2016, Table 303.10. and earlier editions.

Chart 4. Percentage of American College Students Who Are Women

\subsection{Comparative Trends in Degrees by Women and Men, by Level}

Looking at the trends in the percent of college degrees earned by women, we can see that women earned more than half of the Associate degrees by the 1980s, and more than half of the Bachelor's and Master's degrees by 1990s. Women took longer to earn more than half of the Doctorate degree but even that occurred by 2006 and has continued virtually every year to edge up to 52 percent by 2015 .

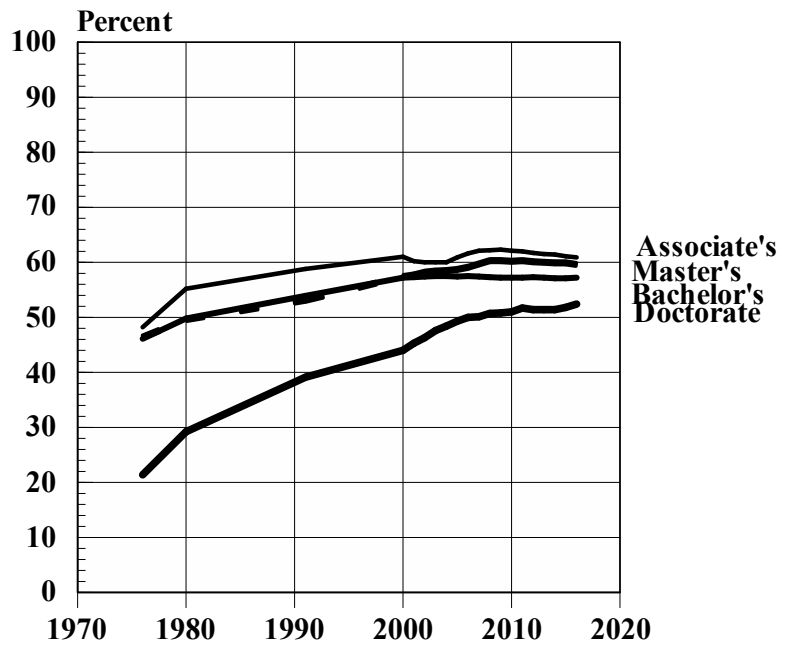

Source: U.S. Department of Education, National Center for Education Statistics, Digest of Education Statistics: 2016, Table 318.10.

Chart 5. Trends in the Percent of College Degrees Earned by Women, 1977-2016, by Level

More specific data on earned degrees by gender show that in the mid-1970s, women earned just less than 200,000 two-year Associates degrees but about 40 years later in 2015, women earned over 200,000 Associate degrees more than men. Also in the mid-1970s women earned about 420,000 Bachelor's degrees which was under the number of 495,000 earned by men. By the 2015 women were earning about one million Bachelor's degrees each year 
which was well over 250,000 more than men. With the Master's degree similar trends were found. In the mid-1970s women earned about 150,000 Master's degrees, which was below the number of about 170,000 earned by men. Again, by 2015, women were earning about 450,000 Master's degrees, well over the 300,000 earned by men.

The most spectacular upsurge by women is at the doctoral level. In the mid-1970s, women were earning only about 20,000 doctorates while the men earned over 70,000, more than three times as many as the women. But by 2015 the women earned about 94,000 doctorates, almost 10,000 more than the 85,000 doctorates that the men earned.

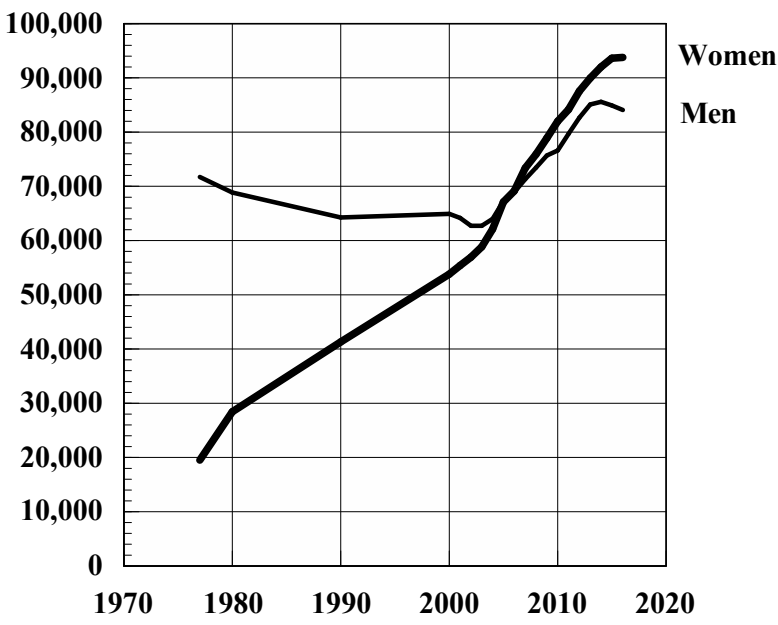

Source: U.S. Department of Education, National Center for Education Statistics, Digest of Education Statistics: 2016, Table 324.20.

Chart 6. Doctorate Degrees Awarded by American Colleges and Universities, 1976-77 to 2015-16, by Gender

\subsection{Trends in the Number of Women and Men Faculty}

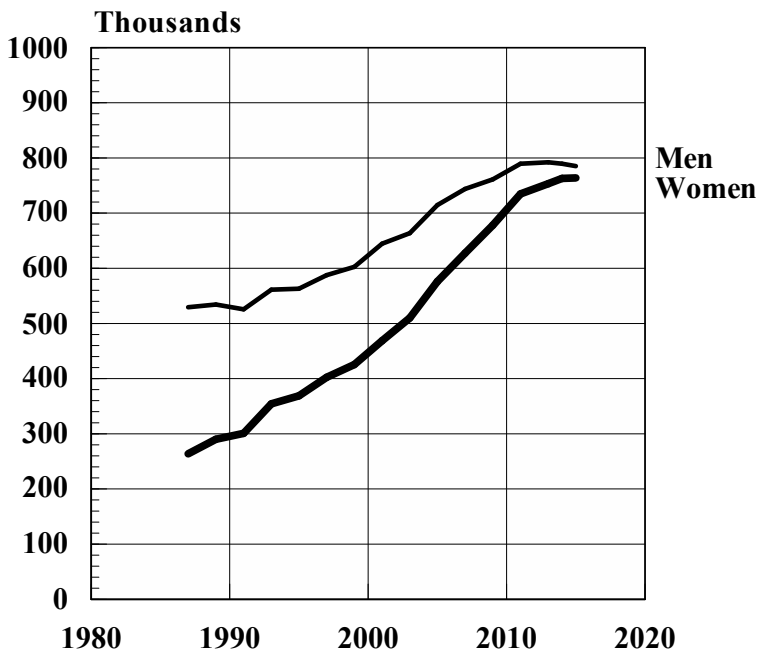

Source: U.S. Department of Education, National Center for Education Statistics, Digest of Education Statistics: 2016, Table 315.10.

Chart 7. Trends in the Number of Women and Men Faculty

By the late 1980s, when the U.S. Department of Education first published faculty data by gender, the
Department reported that there were about 530,000 faculty men and only about 260,000 faculty women. The number of women faculty was less than half the number of faculty men. Over the next thirty years, however, the number of women employed as faculty consistently increased faster than the number of men employed so that by 2016 , the number of women faculty of 764,000 was only 21,000 less than the number of faulty men of 785,000 .

\subsection{Faculty Tenure by Rank, by Gender}

In the belief that tenure increases the fixed costs of higher education, managers have for many years sought cost savings and greater flexibility by eliminating tenure or hiring more faculty off the tenure track. Legislators at the state level are beginning to introduce bills to eliminate tenure for future faculty hires or even to eliminate it for faculty who already have tenure. [6,7] Considering the persistence of the pressure to reduce tenure as a force in higher education, it is quite amazing that tenure is still maintained at virtually all public doctoral institutions and an extremely high percentage of the public master's level institutions. Though the percentage of public two-year institutions with tenure has slipped over the last several decades it is still close to 60 percent.

The percentage of nonprofit, independent doctoral institutions with a tenure system has slipped to about 80 percent, measurably below the virtual 100 percent in the public sector. And while tenure is still in effect in more than half of the public two-year institutions, it has almost disappeared in the private two-year sector.

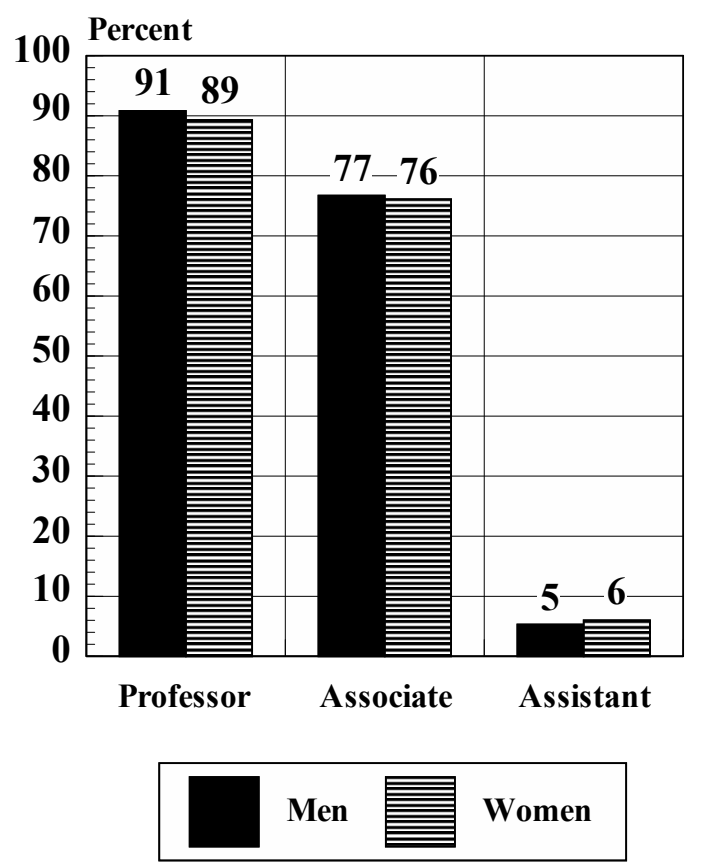

Source: U.S. Department of Education, National Center for Education Statistics, Digest of Education Statistics: 2017, Table 316.80.

Chart 8. Percent of Full-Time Faculty with Tenure at American Colleges and Universities 
Faculty with tenure differs sharply between the public and private institutions, and between the four-year and two-year sectors. Faculty with tenure also differs by faculty rank, with close to 80 to 90 percent of professors being tenured, but only 70 percent of associate professors, and somewhere around 2 to 5 percent of assistant professors.

Remarkably, the percent of faculty with tenure do not vary significantly by gender. As can be seen on Chart 8 , at all colleges and universities combined the percent of women and of men faulty with tenure are very close at each of the three ranks. When comparing the rates of faculty tenure by gender in the two separate public and private nonprofit sectors, not graphed, we find that in both sectors the percent of faculty with tenure is virtually the same for women and men at each of the three faculty ranks.

\subsection{Trends in Employment in American Colleges and Universities, by Gender}

Higher education is a sizeable industry. In 2016, almost four million people were employed by American colleges and universities. This is an increase of more than 1.3 million, or more than 50 percent, over the last twenty-five years. Interestingly, women accounted for 60 percent while men accounted for only 40 percent of the increase in employment in higher education over this period. Just over 2.1 million women were employed in higher education institutions in 2016 which is about 360 thousand more than the 1.7 million men employed.

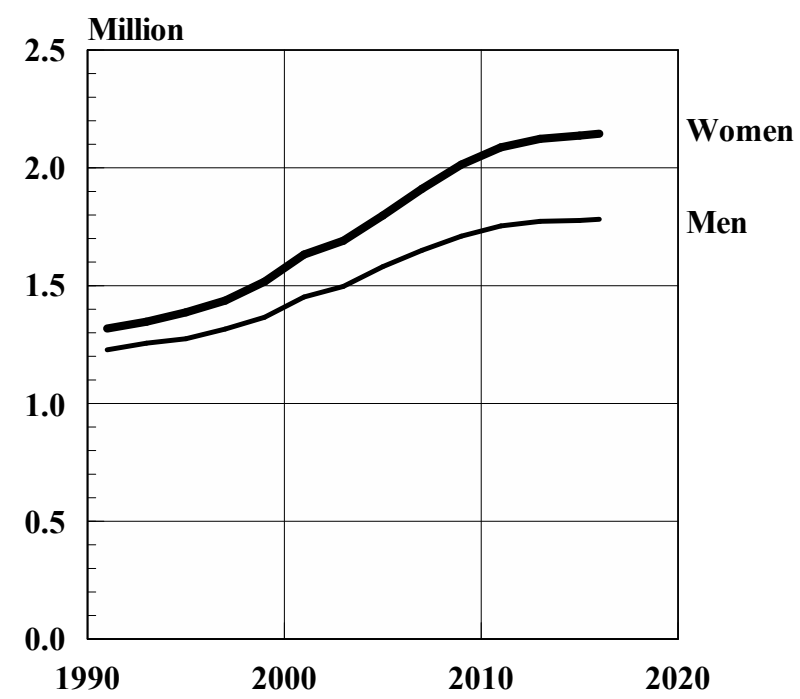

Source: U.S. Department of Education, National Center for Education Statistics, Digest of Education Statistics: 2017, Table 314.20.

Chart 9. Trends in Employment in American Colleges and Universities 1991-2016, by Gender

\subsection{Percentages of Women Employed in American Colleges and Universities, by Position}

The National Center for Education Statistics collects very useful employment data from American colleges and universities. All postsecondary institutions are included in the total. The people employed are characterized as belonging to one of four employment categories: executive/administrative/managerial; faculty. Including those who teach, do research, and those engaged in public service; graduate assistants, and finally, other.

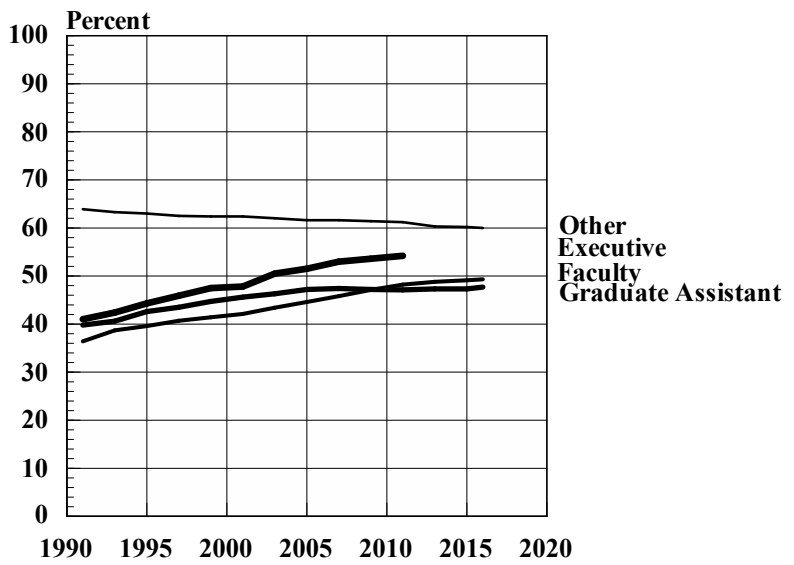

Source: U.S. Department of Education, National Center for Education Statistics, Digest of Education Statistics: 2017, Table 314.20.

Chart 10. Percent of Selected Higher Education Jobs Held by Women 1991-2016

In summary, these charts document the substantial, often spectacular, increases in the participation of women in American higher education over the last thirty to forty years. In every single domain, the women started out participating at lower rates than the men. Then the women caught up with the men in the 1980s and 1990--and now, in virtually every major higher education domain the participation of women comes close to or exceeds that of men.

This is solid success for women in the demographic domain in American higher education. Now, let us look in more detail at the dismaying lack of success women have achieved in the economic domain. These disappointing results are documented on the charts in Part 2 of this report.

\section{Dismaying Lack of Success of Women in the Economic Domain}

Part 1 of this updated report demonstrated the often spectacular increase in the participation of women in almost all aspects of higher education, from student enrollment, and degrees awarded, to faculty engagement. Celebration of these successes is muted by the growing realization that the success stories of women in rates of participation in American higher education that is in the demographic domain, are not matched by similar successes in the economic domain. In fact, the lack of success in the economic domain is utterly dismaying and calls for new, more aggressive policies and actions principally in the political domain. 
Part 2 of this updated report on the status of women in American higher education documents the shortfalls in the economic domain that women continue to experience.

\subsection{Bachelor Degrees in STEM Fields Awarded to Women}

Beginning in the 1970s enormous educational policy emphasis was placed on encouraging women to enter the STEM fields of science, technology, engineering, and mathematics. [8] As measured by the contemporaneous sharp increase in the share of bachelor degrees in these STEM fields earned by women, these policies seemed to be having a very positive impact. The effects did not last, however. By the mid-1980s the number of bachelor degrees earned by women in technology had dropped off precipitously and by 2000 the number in every one of the STEM fields had leveled off or declined substantially, even though the overall number of women earning bachelor degrees was increasing.

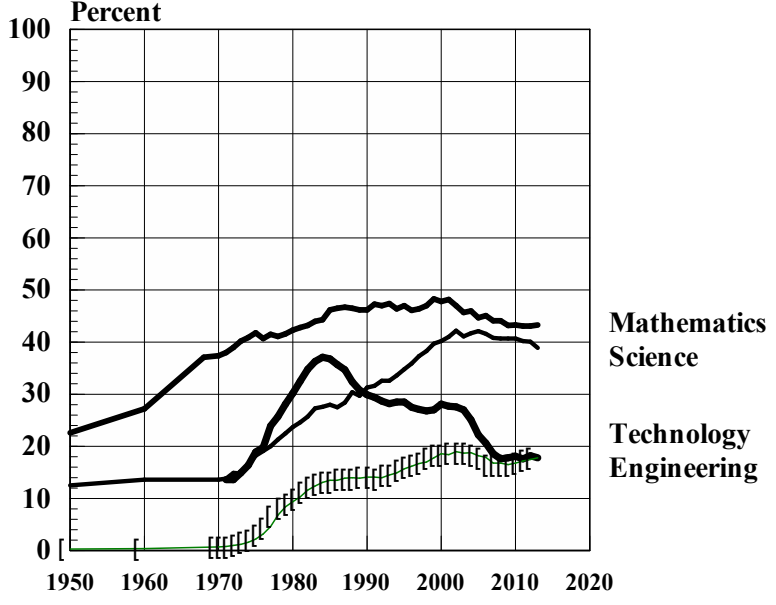

Source: U.S. Department of Education, National Center for Education Statistics, Digest of Education Statistics: 2016, Table 322.20 and earlier editions.

Chart 11. Trends in the Percent of Bachelor Degrees in Stem Fields Awarded to Women 1950-2013

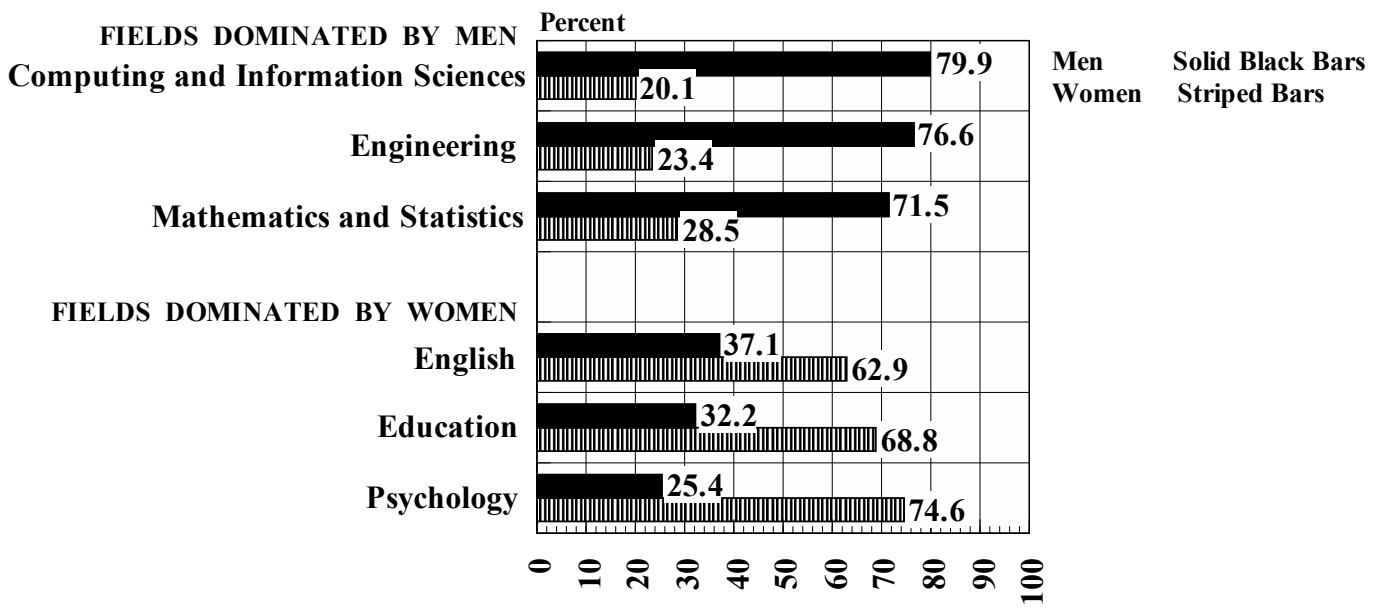

Source: Calculated using data from the U.S. Department of Education, National Center for Education Statistics, Digest of Education Statistics: 2016, Tables 324.30 and 324.35 .

Chart 12. Percent of Students Receiving Doctoral Degrees in Selected Disciplines, 2014-2015, By Gender

\subsection{Degrees Awarded Continue to be Sharply Gendered by Academic Discipline}

Though the overall increase in the college enrollment of women is spectacular, women are enrolled predominantly in social sciences and men are enrolled predominantly in physical sciences. After graduation when women start looking for jobs, they still find that work using the social sciences pays much less than the work men find using their education in the physical sciences.

\subsection{Percent of Faculty who are Women, by Rank}

The percent of faculty at each faculty rank who are women is edging up steadily over recent years. The fact remains, however. that after many years a pattern by rank still persists, with about 30 percent of full professors being women and with 40 percnt of associate professors and 50 percent of assistant professors being women. 


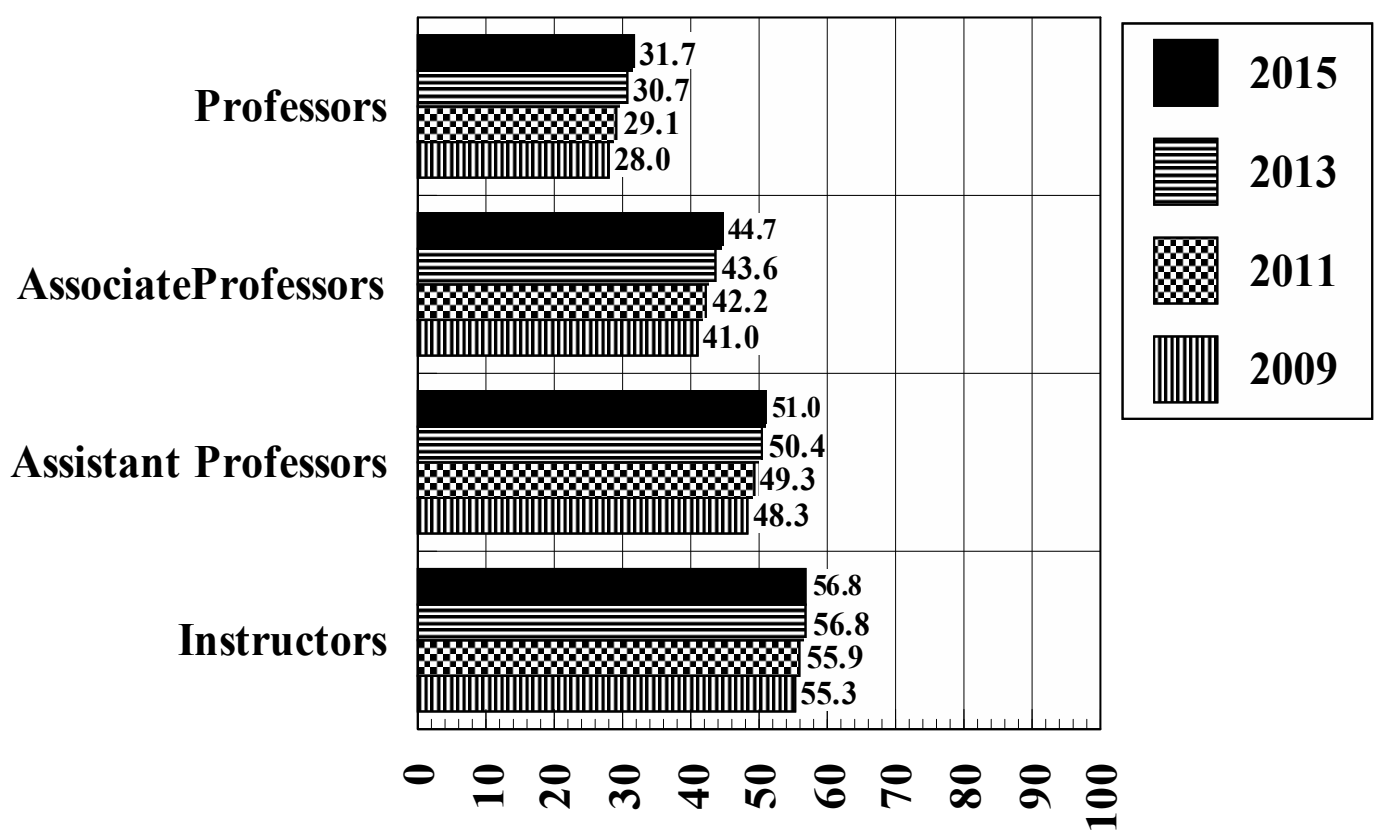

Source: Computed using data from the U.S. Department of Education, NationaLCenter for Education Statistics, Digest of Education Statistics: 2017, Tables 324.30 and 324.35.

Chart 13. Percent of Faculty Who Are Women, by Rank

\subsection{Distribution of Women and Men Within Faculty Activities}

In the 1980s the U.S. Department of Education began a periodic series of the most comprehensive surveys ever conducted of college and university faculty. The National Survey of Postsecondary Faculty (NSOPF) surveys were comducted in 1988, 1993, 1999, and 2004. [9] They included $a$ wealth of information about faculty characteristics and faculty work.

Faculty work is broadly described as falling into three different activities: teaching, research, and public service. The results of the NSOPF surveys showed that the faculty workforce involved in teaching and in public service was about half women and half men. The survey also showed that in the area of research there was a big diffeence by gender: only about 40 percent of the workforcee in research was women while about 60 percent was men. Generally speaking, faculty involved in research are paid higher salaries than those involved in teaching or public seervice. Thus, the men engaged in research activity have access to higher paying jobs than do the women.

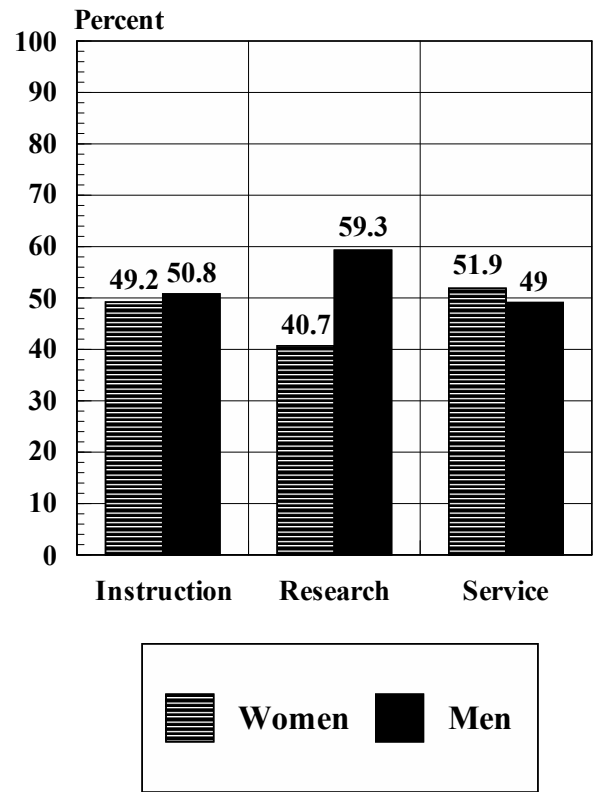

Source: U.S. Department of Education, National Center for Education Statistics, National Survey of Post-Secondary Faulty, 2003.

Chart 14. Distribution of Women and Men Within Faculty Activities 2003 


\subsection{The Growing Gap in Salary Between Women and Men Faculty}

While the number of women faculty has increased dramatically, women are paid less than men at every rank. Women Associate and Assistant Professors are not paid much less than the men at these ranks,. There is, however, a big and growing gap beween the salariesl of women and men full professors. Not only are the women fullprofessors paid less than the men full professors, the salary gap is not narrowing, it is widening.

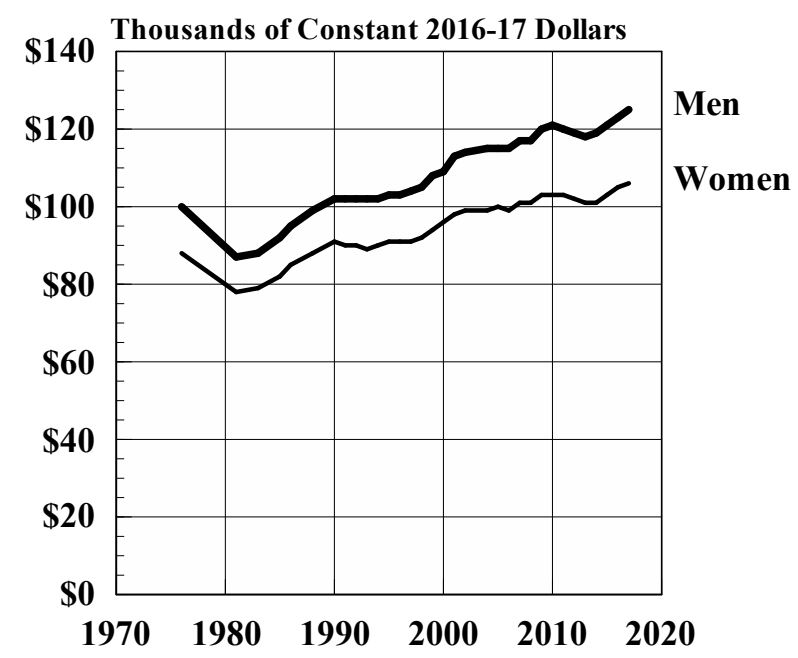

Source: U.S. Department of Education, National Center for Education Statistics, Digest of Education Statistics: 2017, Table 316.10.

Chart 15. The Growing Gap between the Average Salary of Full-Time Women and Men Professors

\subsection{Trend in the Salary of Women Professors as a Percent of the Salary of Men Professors}

It is possible that the lower salary of women professors than of men professors would be accounted for in some part by women becoming professors at a younger age than the older men professors who are retiring. That might explain the existence of a salary gap, but could not be the explanation for a widening gap unless it is argued that the women becoming professors are younger and younger in relation to the age of the older men professors who are retiring - which is probably not the case.

Chart 16 shows the astonishing fact that, measured in constant 2016-2017 dollars, the salary of women professors has declined as a percent of the salary of men professors almost continuously, and relentlessly, over the last thirty years.

On average, the salaries of women professors have fallen from about 90 to 86 percent of the salaraies of men professors over the last three decades. That may not seem like much of a decline, but looked at another way the salary gap increased by 40 percent, from 10 to 14 percent of the average salaries of men professors. In 2016-2017, in dollar terms, the annual salary gap was over $\$ 18,000$ - and that gap is not trivial. If this trend persisted for another 30-year period over a women's career as a professor, this could amount to somewhere near half million dollar shortfall for her.

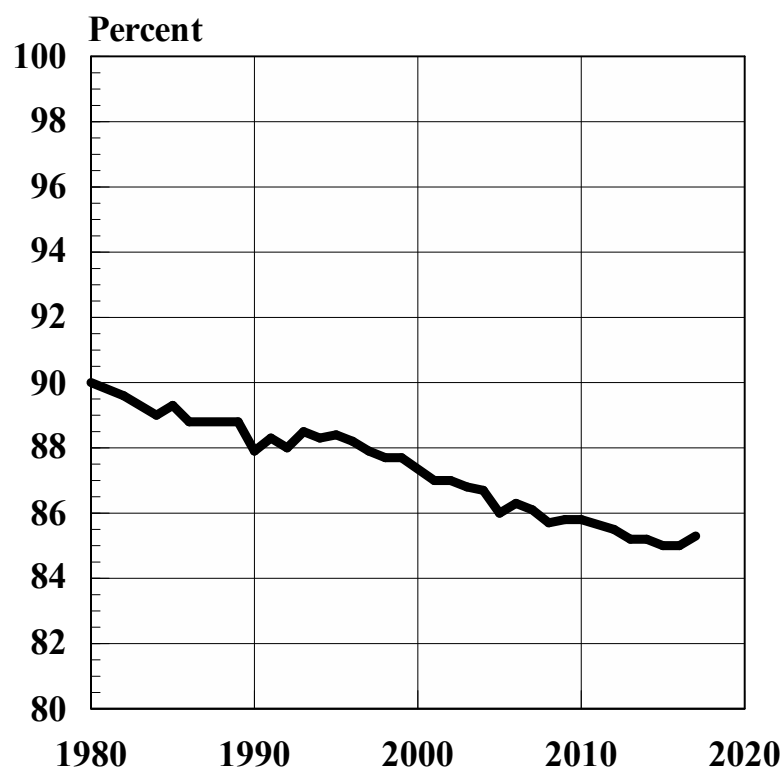

Source: U.S. Department of Education, National Center for Education Statistics, Digest of Education Statistics: 2017, Table 316.10.

Chart 16. The Salary of Women Professors as a Percent of the Salary of Men Professors Full-Time Professors 1980-2016

Note that the American Association of University Professors publishes the results of their annual survey of faculty compensation in the March-April issue of their journal Academe. They also now publish an online only appendix to their report with salaries for individual institutions together with a Salary Equity ratio showing the salary of women faculty as a percentage of the salary of men faculty. [10]

\subsection{Share of Professional Degrees Earned by Women}

The National Center for Education Statistics collects data on selected professional degrees, including specifically law, medicine, and dentistry. In 2015-16 the total number of law degrees earned, counting degrees earned by both women and men, was about 40,000; medicine degrees was just over 18,000; and dentistry degrees was almost 6,000.

Historically, in the 1950s and 1960s, all of these professional degrees were completely dominated by men. Beginning in the 1970s and into the 1980s there was a spectacular increase in the share of all three of these degrees earned by women, rising from under 10 percent to 30 percent of the dentistry degrees, to about 35 percent of the medicine degrees and to over 40 percent of the law degrees. The rise in the share of professional degrees slowed in the 1990s and in recent years has hit a ceiling of just under 50 percent--edging off the peak share of law 
degrees earned by women in 2004, of medicine degrees in 2008 and dentistry degrees in 2013.

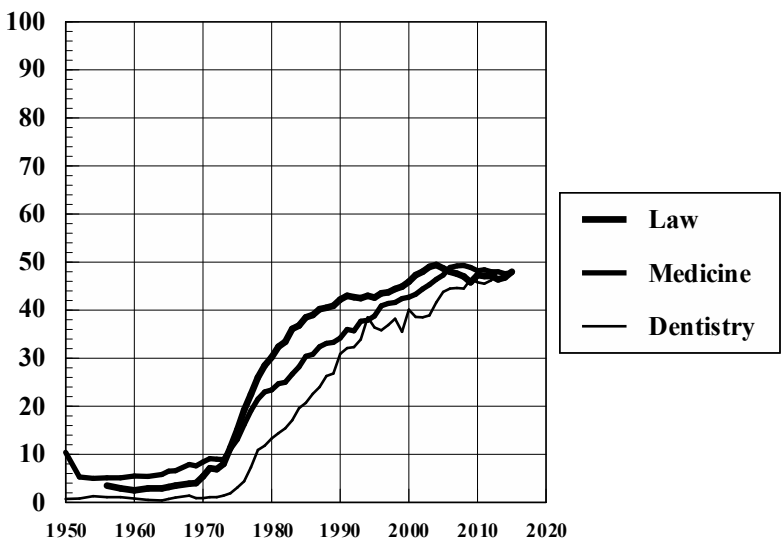

Source: U.S. Department of Education, National Center for Education Statistics, Digest of Education Statistics: 2016, Table 324.40

Chart 17. Share of Professional Degrees Earned by Women, 1950-2016

\subsection{Women Serving as College and University Presidents}

Women have been making concerted efforts since at least the 1970s to reach the highest level of leadership in higher education and become college or university presidents. The American Council on Education (ACE), whose college and university members are represented by their presidents organized special mentoring and other professional development programs to prepare women to take on the responsibilities of the presidency.

The periodic studies of the American College President made by ACE, show that women are making steady but slow progress toward the goal of becoming college and university presidents. Since the mid-1980s women increased their share of all institution presidents from 10 percent to 30 percent. $[11,12]$ Once again, if we look more closely at the share of presidents of institutions grouped by level, we find that the higher the level of resources or prestige, the smaller the share of presidents who are women. At the highest level in 2016, among doctorate granting institutions in the public sector 23 percent of the presidents were women, and in the private sector 20 percent were women.

The ACE study found that the route to the presidency may be different for men and for women. Most women come up through the ranks within the institution, serving first in the traditional sequence of Department Chair, Dean, and Chief Academic Officer. Some of the men are promoted to president from industry, coming from outside higher education. A smaller percentage of women than men executives would limit the representation of women in the industry pool from which college presidents are selected.

In the 1970s the use of outside consultants to aid or to replace inside presidential search committees was virtually unknown. In recent years, outside consultants are used much more frequently. Some observers have speculated that as higher education is perceived as facing intensifying challenges; those vetting prospects would favor older, more experienced executives, [13] that is men over women, unless they were formally instructed to reach out to include women in the pool.

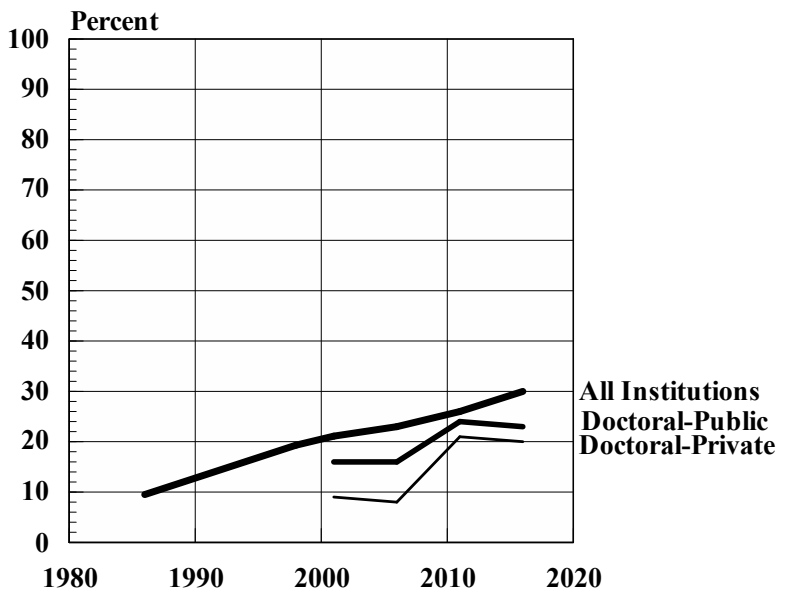

Source: American Council on Education, The American College President Study, 2017 and earlier editions.

Chart 18. Percent of College and University Presidents Who Are Women, Selected Years 1986-2016

\subsection{Women on College and University Governing Boards}

Boards of Trustees of the colleges and universities play an important role in setting the priorities and tone on their campuses. The presence of women on these boards can be significant in setting a goal of gender equality and gender equity and implementing policies focused on making progress.

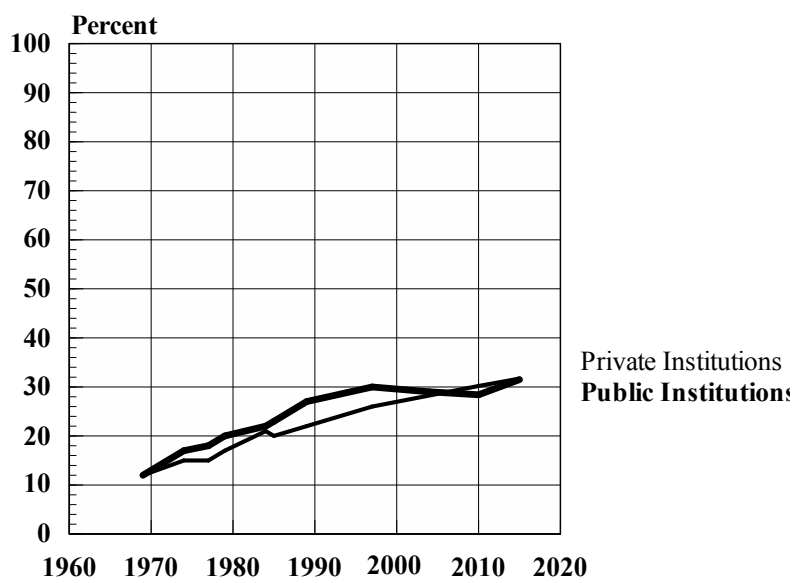

Source: Association of Governing Boards of Universities and Colleges, Survey of Board Composition, 2015.

Chart 19. Percent of College and University Governing Board Members Who Are Women 
The Association of Governing Boards of Universities and Colleges collects data on the numbers of women and men on boards. Their report on the 2015 Survey of Board Composition [14] includes historical data showing that there was a surge in the participation of women on college and university boards beginning in the 1970s that lasted about 20 years to 1990 .

Women were only about 10 percent of board members in the early 1970 s, but climbed steadily to about 30 percent over the next two decades to 1990. In the quarter century since 1990 there has been barely any increase in the percentage of women on college and university governing boards. It appears that the share of women on governing Boards has hit a low ceiling.

The AGB 2015 Report also includes information about the share of women on governing boards by level of institution. As shown on Chart 20, the higher the level of the institution, the smaller the percentage of women on the governing board. At colleges offering associate degrees, on average, women held about 38 percent of board positions but the percent drops to about 26 percent at the statewide or other multi-campus system level.

There are also differences in the responsibilities of women and men board members. Typically, the chairs of the powerful finance committees are men and the chairs of less powerful human resource committees are women.

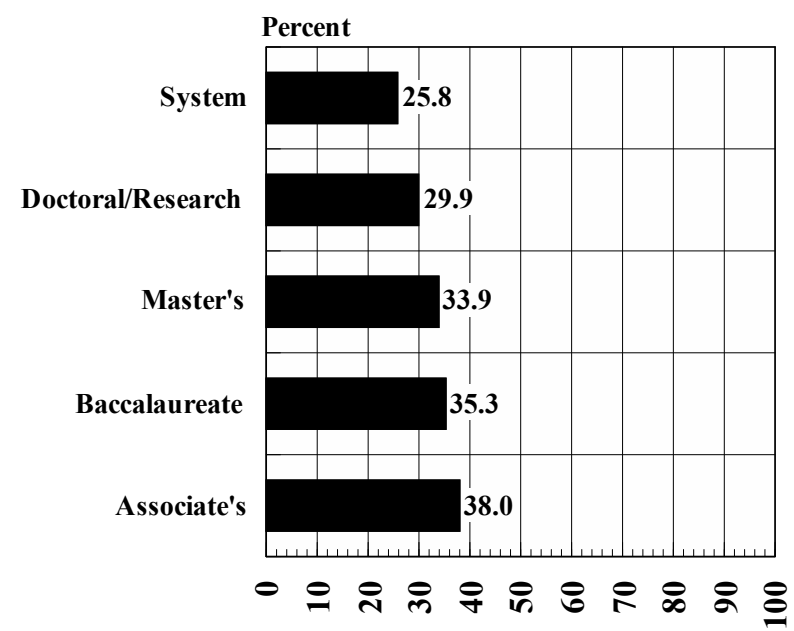

Source: Association of Governing Boards of Universities and Colleges, Survey of Board Composition, 2015 and Colleges, Survey of Board Composition, 2015.

Chart 20. Percent of Women on Governing Boards by Level of Institution 2015

\section{Conclusions}

First, there has been a spectacular increase in the participation of women in virtually all aspects of American higher education. Enrollments have increased, several hundred thousand more women than men are enrolled in college. More degrees are being earned by women than men at each level, more bachelors and masters degrees, and now even more doctorate degrees are being earned by women than men. The number of women faculty has increased so much that as of 2016 there are almost as many women as men faculty. Women are also awarded tenure at about the same rates as men at each faculty rank.

Second, however, this success in participation in the demographic domain has not been accompanied by a commensurate success in the economic domain. College enrollments of women are skewed into the social sciences which prepare women for lower paying jobs than the physical sciences that the men dominate. A surge in the 1970s of women earning bachelor's degrees in the STEM fields of science, technology, engineering, and mathematics almost completely dissipated a few years later.

Faculty women are paid less than the men faculty, particularly at the level of full professor. And the salary gap is not decreasing, it is increasing. The percent of faculty who are women drops off sharply ascending the ranks from assistant, to associate, and finally to full professor.

There have been small but steady increases in the number of women becoming college and university presidents and in the number of women on college and university boards of trustees in the 1970s into the 1980s. Progress in both of these leadership domains began, to wane in the 1990s and in recent years has apparently hit a low ceiling.

Speaking as an economist, I see that we have tools to describe trends but our tools do not help us do much to explain why there was a burst of activity in the 1970s nor explain why there was a falloff in the 1990s. Other disciplines may have better tools for explaining behavior. Women concerned about equality would benefit if economists joined forces with sociologists and anthropologists to explain both the positive drive and the negative fall off. Working together could develop better ideas and more effective recommendations to speed up positive change.

Together, we should ask and try to answer three questions:

1. What accounts for the surge of positive actions beginning in the 1970s moving women in the direction of greater equality in American higher education? How important were affirmative action policies [15] and Title IX legislation prohibiting sex discrimination in programs receiving federal funding [16]?

2. What happened beginning in the 1990s to slow down and even in some cases halt this progress?

3. What do we need to do to restore the positive energy and start moving once again toward greater equality for women in the economic domain in higher education?

\section{Findings}

This paper documents three major findings: 
1. Women have been highly successful in the demographic domain, with large numbers entering the pipeline into American higher education.

2. Women have not been equally successful in the economic domain, being concentrated by gender in lower-paying fields, and being paid less for equivalent faculty work.

3. Progress toward gender equality is not linear over time but advances in waves. The period from the 1970s into the early 1980s was characterized by a burst of activity moving toward gender equality goals, but then beginning in the 1990s and lasting for another twenty years or more--until now--the rate of progress has slowed and even plateaued.

\section{The Role of Gender}

Gender is overwhelmingly important for most human beings as the central feature of their self-perception and identity. If differences are found between women and men, the classic debate is whether these differences are the result of inherent nature or experiential nurture.

As neuroscience, and specifically gender science, advances, however, it appears that nature vs. nurture is a false and misleading overly simple dichotomy because the relationships between nature and nurture are actually coming to be understood as complex and interactive. The expression of a particular gene, for instance, can be influenced by such environmental factors as heat or light or exposure to chemicals or hormones. [20]

The currently contentious issue which remains after decades of dealing with gender gaps is whether the differences in outcomes between women and men is the result of discrimination or the result of choices that the women themselves make.

\subsection{A Life Cycle Approach to Gender Differences}

Drawing on both research and speculation, it may be useful to employ a Life Cycle Approach to examining the alternative explanations for different economic outcomes for women and men in academia. Are the persistently lower returns for women than for men the result of women's own choices-or are they the result of discrimination?

A Life Cycle Approach would begin with the experiences of children, and then examine the impact of family on girls and women, both the parental family and the woman's own family. Next women working in academic institutions and then women in the workplace in general, including women in business would be examined. Finally, society as a whole could be explored to speculate how it might impact women differently from men in ways which create and sustain the gender gap.

\subsection{Differences between Girls and Boys That Could Initiate a Gender Gap at a Very Early Age}

Starting with a popular overview of the more scientific research on differences between girls and boys the overall conclusion is:

With respect to development and behavior, the differences between girls and boys are small and "have more to do with experience than with gender." It may be possible to explain differences between boys and girls by nature, taking into account differences in exposure of the fetus to testosterone but the parental preference for a girl or a boy might affect the nurturing experience of infants differently.

Though the differences are small, on average, baby girls are reported to be able to discern human emotion earlier than baby boys by interpreting facial expressions. Baby girls talk earlier and have larger vocabularies than baby boys. Baby boys are reported to have better spatial abilities than baby girls in understanding size, space, and the distance between objects. Baby girls are more attuned to the sound of the human voice than are baby boys, and thus may be better listeners. Differences in the toys parents offer to girls and boys typically begin or reinforce the process of creating differing stereotypes for children. [17]

\section{Recommendations}

1. It is never too early to start to broaden the horizons of girls.

2. Encourage parents to give girl children a wide range of playthings, not just stereotypical toys--offer girls building blocks as well as dolls.

3. Introduce numbers to girls very early. Encourage active play for both girls and boys.

\subsection{Difference between the Parental Family Influences on Girls and Boys}

Children are socialized in important ways through the influences of their families. Predominantly, girls are taught to be modest and dependent while boys are taught to be gregarious and independent.

It might be observed that many of the girls who later become successful in non-traditional roles have experienced the special support and encouragement of their fathers.

\section{Recommendation}

Parents should introduce girls to a broad array of life choices, including non-traditional as well as traditional roles.

\subsection{Differences between Girls and Boys in the Classroom}

In recent years there has been extensive research 
showing that teachers believe gender matters in the school classroom because girls and boys have different learning styles. But then the next question is whether these observed difference in learning styles are because the brains and cognitive development of girls and boys are inherently different, or because girls and boys are treated very differently even from birth.

Differences between girls and boys have been observed more recently in brain size, structure, and rate and sequence of development. Girls have more fully developed connections between the left and right lobes of their brains which might enhance their ability to deal with complexity. Girls mature at an earlier age. Girls have greater sensory perception and can see, hear, and smell better than boys. The differences between brains of girls and boys would all seem to favor girls in the classroom. These differences might help to account for the fact that girls get better grades than boys, are more likely to be concerned about how well they are doing in school, to persist, and to graduate than are boys.

The differences between girls and boys favor girls in classroom setting and they are manifest in the higher academic performance of girls in elementary school. Yet, before children reach middle school, the girls have lost their self-confidence and characteristically underestimate their abilities while boys overestimate their abilities.

Dr. Catherina Scott has done research that supports her conclusion that "gender does matter, but it matters because it determines most significantly how we treat children and what we expect from them." Boys and girls differ in the home learning environments that parents provide, which lead directly to differences in school achievement. [18]

\section{Recommendations}

1. Teachers should develop curricula and offer classroom activities that build and continue to strengthen the self-confidence of girls.

2. Teachers should encourage girls to take the classes in middle school that they will need to prepare for high school that they will subsequently need to prepare for college.

\subsection{Differential Impact on the Work-Life Balance of Academic Women and Men of their Own Families}

Both women and men face the issue of how to balance work and life. The Times Higher Education recently published an impressively comprehensive survey of the work-life balance of women and men academics in the United Kingdom, Australia and the United States. The survey confirms that the strains of parenthood are felt by 43 percent of the women academics, a much higher percentage than the 25 percent of the men academics. About 26 percent of the women report that they are responsible for more than half of the child care, 15 percent of the women report that they perform most of the child care, and 7 percent report that they do all of the child care-compared with reports respectively by 4 percent of the men that they do half of the child care, by 2 percent that they do most, and by 1 percent that they do all of the child care. Forty percent of men reported that children would "not at all" hold back their careers, compared with only 20 percent of women who so reported.

Academics were asked about how their salaries compared with the salaries of their partners and the women reported "less" or "a lot less" while the men reported "more" or "a lot more." Research confirms that women, even women who are the main bread winner in the family, bear heavier burdens than men of care for children or elderly parents and of housework. [19]

It was widely anticipated that the internet would create more flexible working conditions and to some extent improve the work-life balance for both women and men adept with the technology. It appears however, that the opposite is the actual result. The internet and immediate accessibility have apparently obliterated the boundary between work and life, leading to a deterioration of the work-life balance, possibly more so for women than for men.

\section{Recommendations}

1. Help women negotiate with their partners a more equitable balance among their shared responsibilities.

2. Encourage open discourse between men and women about work-life options and priorities to help establish a wider range of acceptable norms for both women and men.

\subsection{Barriers to Gender Equity for Women within Academic Institutions}

Hiring and Promotions. There are many direct and indirect more subtle barriers to gender equity for women within academic institutions. Vestiges of overt discrimination prevailing in earlier decades still remain. In many departments the older men still weigh most heavily in the hiring and promotion decisions. Women have terminated pregnancies out of fear of contract non-renewal. [19]

Culture of Secrecy. A culture of secrecy pervades most academic institutions with respect to salaries. Women do not know and cannot ordinarily learn about how their salaries compare with those of their male counterparts. If women are initially hired at a lower rate, it is not likely that they can ever make up the difference.

\section{Recommendations}

1. Encourage women to apply for desired positions and to nominate themselves for promotion.

2. Strive to convert the academic culture of secrecy into a culture of transparency.

3. Know the statistics. Track down the facts about salaries. Find out how much women and men are actually 
paid for the same work and use that information in making salary demands.

4. Become tougher negotiators. Do not just accept the first offer. Negotiate terms more forcefully. Figure out how best to inform and engage the human resource officers, union collective bargaining agents, and search committees and search consultants who might be able to help work toward real equality for women.

\subsection{Barriers to Gender Equality and Gender Equity in Society as a Whole}

Gender Equality and Gender Equity are not the same concepts and are not interchangeable. Gender equality refers to treating women and men equally, without limitations imposed by stereotypical gender roles or prejudice.

Gender Equity means treating women and men fairly. Rights, responsibilities, and opportunities of women and men should not depend on whether they were born female or male. [21]

\section{Recommendations}

1. Introduce, implement and sustain "gender mainstreaming" as a major strategy for achieving gender equality and gender equity in society as a whole. Gender mainstreaming requires careful and thorough evaluation of any differential impact on women and men of any policy, program, or budget.

2. Become more radical. Become sharper and more articulate on your own campus, and locally, statewide, and nationally. Do not just extrapolate recent rates of progress into the future and sit back complacently thinking we can just wait for equality. Where women are concerned, positive trends often hit ceilings, plateaus, or even drop off, slowing or arresting progress. Stay aggressive.

3. Support women colleagues. In debates, reinforce cogent statements by other women. Take risks with other women putting their careers on the line.

4. Collaborate across generations of women who may have different experiences and skills. Vote for women with shared values.

5. Take leadership roles. Build coalitions with other women in other pursuits. Run for office. Most important, getting into the high-level positions where key decisions are actually made in both the public and private realms.

\subsection{Launch a Second Wave of Activity to Achieve Gender Goals}

Progress toward gender goals is not linear. This is the third general conclusion documented by the trend data presented in this paper. The trend data that cover recent decades underscore the fact that progress toward goals of gender equality and gender equity is not linear. Progress is clearly not continuous but proceeds with positive bursts of activity which are followed by periods of negative weariness, reaction, push back, and fall off.

\section{Final Recommendation}

It is time for an aggressive new push for a Second Wave of dedicated activity to promote Gender Equality and Gender Equity Goals

\section{Reflection}

Right now in 2018 something quite new and palpably different is happening. Our country has changed, inspired by the strength and vision of the high school students from Parkland, Florida who are fighting gun violence. They are envisioning change as possible which they had earlier been told was impossible. In this new atmosphere of hope for change, our old social and economic challenges could also break through and become new possibilities.

\section{Acknowledgements}

I wish to acknowledge the extremely helpful assistance in providing essential data by Daniel J. Foley, Survey Statistician, of the National Science Foundation; Kristen Hodge-Clark, Director of Research, at the Association of Governing Boards of Universities and Colleges; and Jonathan Turk, Center for Policy Research and Strategy, American Council on Education.

Note: This paper is a new update and expansion of a presentation made initially to the International Association for Feminist Economics 25th Annual Conference in Galway, Ireland on June 26, 2016 titled "The Painfully Slow Transitions and Uneven Transformations Toward Gender Equality in American Higher Education - and Ideas About How To Make Faster Progress."

In addition, earlier data was used in a chapter titled "Women in American Higher Education: A Descriptive Profile," in a book edited by Heather Eggins and published in Europe titled The Changing Role of Women in Higher Education: Academic and Leadership Issues, Springer International Publishing, AG Switzerland, 2017, pages $31-52$.

\section{REFERENCES}

[1] Frances, C., and Mensel, F. R., Women and Minorities in Administration of Higher Education Institutions: Employment Patterns and Salary Comparisons, 1978-79 and An Analysis of Progress Toward Affirmative Action Goals 1975-76 to 1978-79, Journal of the College and University Personnel Association, Volume 32, Number 3 (1984), 77 pages. Available in the ERIC System at EJ258140. 
[2] Massachusetts Institute of Technology, A Study of the Status of Women Faculty in Science at MIT, The MIT Faculty Newsletter, Volume XI, Number 4 (March 1999 Special Edition)

[3] Johnson., H. L., Pipeline, Pathways, and Institutional Leadership: An Update on the Status of Women in Higher Education, American Council on Education, Center for Policy Research and Strategy, Washington, .D.C., 2017, 24 pages.

[4] U.S. Department of Education, National Center for Education Statistics, Digest of Education Statistics. Annual editions.

[5] National Science Foundation, National Center for Science and Engineering and Statistics, Survey of Doctorates, 2015.

[6] Flaherty, C., Killing Tenure: Legislators in Two States Seek to End Tenure at Public Colleges and Universities, Inside Higher Ed, January 13, 2017.

[7] Leiter, B., Academic Ethics: Rethinking the Justification of Tenure, The Chronicle of Higher Education, January 17, 2017. Available at

https://www.chronicle.com/article/Academic-Ethics-Rethin king/238888.

[8] White House, Office of Science and Technology Policy, Women in STEM. Statement by President Barack Obama, February 2013. Available at

https://obamawhitehouse.archives.gov/administration/eop/o stp/women.

[9] United States Department of Education, National Center for Education Statistics, National Survey of Postsecondary Faculty (NSOPF), Surveys were done in 1988. 1993, 1999, and 2004.

[10] American Association of University Professors (AAUP), The Annual Report on the Economic Status of the Profession, 2015-16, Academe, March-April, 2017.

[11] Gagliardi, J. S., Espinosa, L.L., Turk. J. M., and Taylor, M., American College President Study: 2017, American Council on Education, Washington, D.C.
[12] American Council on Education, The American College President, 2007, Table 4.

[13] Curtis, J. W., (Director of Research and Public Policy, American Association of University Professors), Persistent Inequality: Gender and Academic Employment, a presentation prepared for "New Voices in Pay Equity," an event which was part of Equal Pay Day, April 11, 2011, available on the AAUP website at https://www.aaup.org .

[14] Association of Governing Boards of Universities and Colleges (AGB), 2015 Survey of Board Composition.

[15] University of California-Irvine, Office of Equal Opportunity and Diversity, A Brief History of Affirmative Action. Available at http://www.oeod.uci.edu/policies/aa history.php.

[16] United States Department of Justice, Overview of Title IX of the Education Amendments of 1972. Available at https://www.justice.gov/crt/overview-title-ix-education-am endments-1972-20-usc-1681-et-seq.

[17] Sethi, A., Parenting, The Real Differences Between Boys and Girls: What the Research Really Says About Gender and Babies. Available on the internet at https://parenting/article/real-differences-between-boys-and -girls.

[18] Lobo, I., (2008) Environmental Influences of Gene Expression, Nature Education, 1(1), 39.

[19] Bothwell, E., The Times Higher Education Work-Life Balance 2018 Survey, February 8, 2018. Available at https://www.timeshighereducation.com/features/work-lifebalance-survey-2018.

[20] Skeates, A., What Does the Work-Life Balance Mean in the Age of the Internet? Available at https://insight-international.org/what-does-work-life-balan ce-mean-in-the-age of-the-internet.

[21] A Global Commitment to Gender Equality and Gender Equity: A Summary Review of UNESCO's Accomplishments Since the Fourth World Conference on Women (Beijing 1995), Available at unesdoc.unesco.org/images/0012/001211/ Fourth World Conference on Women121145e.pdf. 